\title{
Work-related stress and employee engagement among millennial workforce in the new normal
}

Vigo, Eva May A. $\bowtie$

Laguna College of Business and Arts, Philippines (evamayvigo91@gmail.com)

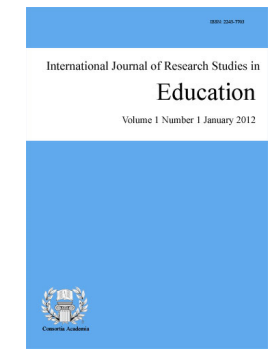

ISSN: $2243-7703$

Accepted: 5 August 2021 Online ISSN: 2243-7711

OPEN ACCESS

\section{Abstract}

The main focus of this study was to determine the current levels of work-related stress and employee engagement at the time of pandemic and to rule out significant relationship between the two variables and the effect of work-related stress to employee engagement among the millennial workforce of First Philippine Industrial Park in Batangas. The proposed action plan to manage work-related stress and improve employee engagement in the new normal was the output of the study. This study utilized the causal research, non-experimental method design. Through cluster sampling, the respondents of the study were 427 millennial locator employees of First Philippine Industrial Park in Batangas. Standard questionnaires such as the Job Stress Scale, and Utrecht Work Engagement Scale (UWES-17) were used as survey instruments for gathering of data. Using the four-point and seven-point Likert Scale, the simple mean, and multiple regression analysis, findings revealed that the levels of work-related stress was high and the levels of employee engagement was extremely high among the millennial workforce at the time of the pandemic. Work-related stress specifically Demand had significant relationship with employee engagement specifically Vigor and Dedication but had no significant relationship with Absorption. Work-related stress specifically Control had significant relationship with employee engagement specifically Dedication and Absorption but had no significant relationship with Vigor. Finally, work-related stress specifically Support had significant relationship with employee engagement specifically Vigor and Absorption but had no significant relationship with Dedication. Work-related stress particularly Control significantly impacted Employee Engagement in terms of Vigor and Dedication, while Demand and Support in terms of Absorption.

Keywords: work-related stress, employee engagement, millennial workforce, new normal 


\section{Work-related stress and employee engagement among millennial workforce in the new normal}

\section{Introduction}

The global workforce is now dominated by a totally new generation - the Millennials. As early as 2018, it was estimated that fifty percent $(50 \%)$ of the labor force will be comprised of millennials by 2020 and will rise to seventy-five percent $(75 \%)$ by 2025 , according to benchmarking performed by Aon Human Capital. These statistics translate to a substantial shift in the workplace in terms of culture, norm, and trend as compared to the previous generation. The problem is, the majority of the workforce are known to switch jobs easily which translates to high attrition or turnover rates. In the Philippines, millennials are known for job-hopping. They do not mind switching from one job to another as long as they do not get the satisfaction that they are looking for, unlike the previous generation who are known for staying in the same job for a long time. The millennials do not settle for a job that they are not "happy" with. They are not afraid to start anew and seek a job that will give them purpose and career growth. But why do millennials leave their jobs? One of the reasons that may be pointed is stress in the workplace.

The millennial generation is said to be the most stressed generation. In a survey conducted by Lhasa OMS in 2,000 millennials in the US to determine the causes of stress and burnout in millennials, sixty-five percent $(65 \%)$ said it was due to work stress, whereas, seventy-eight percent (78\%) of those surveyed think that they are most stressed as compared to the previous generations due to more debt, more competitive job market, and more expensive healthcare. There are different work stressors that an employee may encounter at work every day but the most common ones include a heavy workload with unrealistic demands, lack of freedom in making work-related decisions, and inadequate support from superiors and/or colleagues. Prolonged exposure to work stressors, wherein a person is not able to cope effectively, may cause job strain which is known to negatively affect physical and mental health which may foster negative feelings towards work such as lack of enthusiasm, laziness caused by the inability to feel satisfaction in doing the work, and disengagement or loss of interest at work. In this case, companies must come up with strategies on how employees can successfully cope with work-related stress, as well as, ways on how to avoid the abovementioned negative effects.

This is where employee engagement comes into the picture. What is employee engagement? William Kahn was the first person to formally define this human resource concept. According to him, employee engagement is "the harnessing of organization members' selves to their work roles; in engagement, people employ and express themselves physically, cognitively, and emotionally during role performances". The level of employee engagement dictates the strength of the psychological connection that an employee feels towards their work. In other words, employee engagement is driving employees' enthusiasm, commitment, and preoccupation towards work, so they can give their best at work every day.

Driving employee engagement is never a walk in the park. It involves doing something that aims to influence the employees in a way that makes them feel motivated to work with their finest effort. Common employee engagement activities include trainings, workplace parties, sports events, company outings, team bonding, among many others. Not only with activities, but companies also invest in their workplace facilities to enhance employee engagement such as the provision of recreational room, sleeping quarter, spacious pantry area, and even a good office view. Availability of high technology work equipment and accessibility of work application and software also contribute a great deal.

Then, the COVID-19 pandemic happened. This caused major changes in people's way of life. Physical distancing, wearing of face mask and face shield in public places, transport restrictions due to community quarantine, and lockdown. This change also hit the working sector - strict health and safety protocols on-site, 
work from home arrangements, telecommuting, online meetings, and training, and now some companies even do employee engagement activities like Christmas parties to implement social distancing and prevent the spread of the virus. In this kind of set-up, how is the millennial workforce coping? How are the changes caused by the pandemic affect their work-related stress? Are companies able to maintain their employees engaged when "human touch" is not recommended? The researcher chose this study to determine the current status of the millennial workforce in terms of their work-related stress and its effect on employee engagement in the time of the new normal. This study aims to bring about awareness and help companies come up with an approach to address the situation in their organizations.

\subsection{Theoretical/Conceptual Framework}

This research used established theories and utilized its principles to serve as the framework for the flow of the study. First, is the Strauss-Howe Generational Theory (1991), also known as the Fourth Turning Theory. According to the theory, historical events are associated with recurring generational personas (archetypes). Each generational persona unleashes a new era (called a turning) lasting around 20-25 years, in which a new social, political, and economic climate (mood) exists. These theorists were the brains behind the terminologies used to define generational cohorts such as Baby Boomers, Gen X, Gen Y or Millennials, and Gen Z. As applied in the study, this theory supports the idea that coming from the same generation, millennials tend to have a certain pattern of values and behavior that can be observed in the workplace. It was evident with the difference of the workforce belonging from the previous generations and now.

Second, is the Job Demand-Control-Support Theory. Originally the Job Demand-Control model (Karasek, 1979), the Job Demand-Control-Support Theory (Johnson \& Hall, 1988) is the most popular in the Occupational Health Psychology research. This model suggests that employees who have lesser freedom in making work-related decisions combined with a heavy workload and high work demand may cause job strain that affects physical and mental health. This theory relates to the study in defining the potential source of work-related stress in the millennial workforce. Millennials are known to love freedom, flexibility and the opportunity to express themselves and this theory would explain perfectly how to the millennials workforce in terms of coping with work-related stress and how employee engagement can be strategized.

The concept of the study suggests that a workplace that is characterized by a job with high demand, low control, and low support results in a workplace with high work-related stress. As a consequence, poor employee engagement follows, having Poor Vigor, Poor Dedication, and Poor Absorption as its manifestation. In summary, the study proposes that work-related stress negatively affects employee engagement, in a way that high work-related stress results in poor employee engagement. This assumption was proven by several studies conducted before the COVID-19 pandemic. Thus, the researcher would like to study these variables at the time of the new normal.

\subsection{Research Paradigm}

In this study, the researcher focused on identifying the current level of Work-Related Stress and the level of Employee Engagement among the Millennial Workforce during this time of the pandemic, or what we call the "New Normal" and their possible relationship. Meaning, are employees with a high level of Work-Related Stress possess a low level of Employee Engagement, and vice versa.

Figure 1 shows the main concept of the study. The study determined the effect of Work-Related Stress in terms of Job Demand, Job Control, and Workplace Support on Employee Engagement in terms of Vigor, Dedication, and Absorption among the Millennial Workforce in the New Normal from the locator companies of First Philippine Industrial Park in Batangas. 


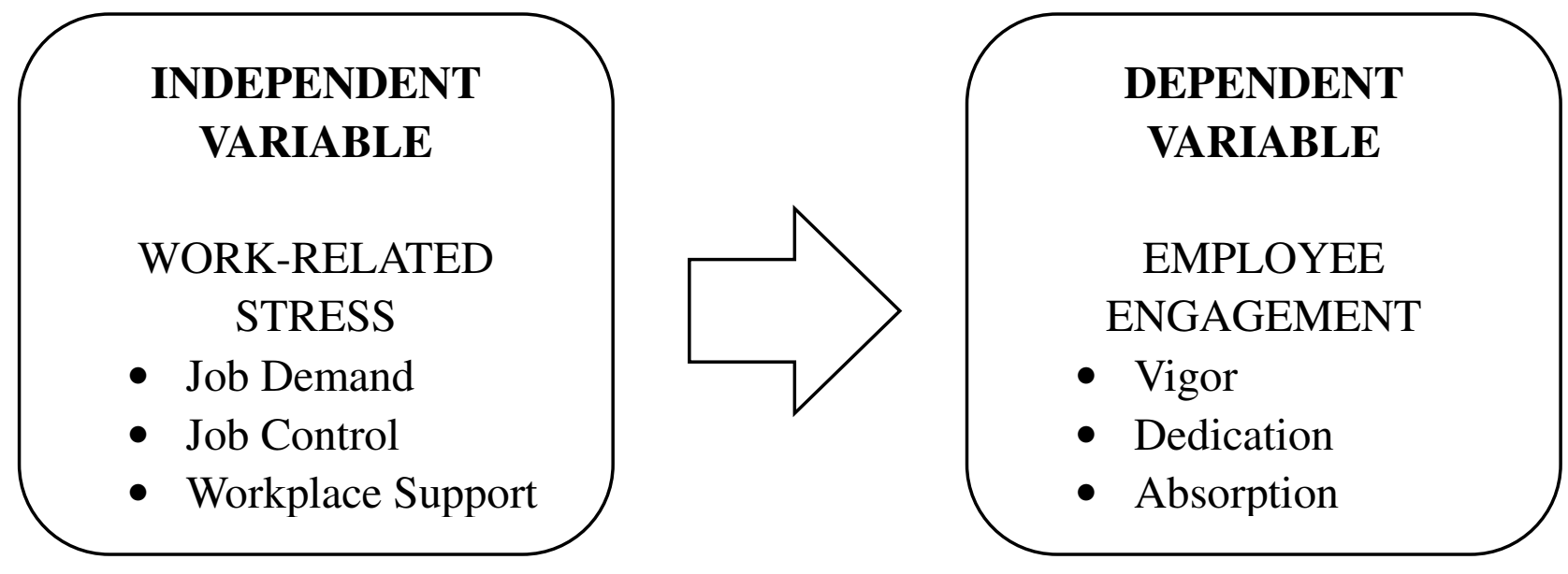

Figure 1. Research Paradigm

\subsection{Statement of the Problem}

The main thrust of this study was to determine the Work-Related Stress and Employee Engagement among Millennial Workforce in the New Normal in First Philippine Industrial Park.

$>\quad$ What is the level of work-related stress among the millennial workforce in the New Normal in First Philippine Industrial Park in terms of: Job Demand, Job Control, and Workplace Support?

$>\quad$ What is the level of employee engagement among the millennial workforce in the New Normal in First Philippine Industrial Park in terms of: Vigor, Dedication, and Absorption?

$>\quad$ Is there any significant relationship between work-related stress and employee engagement among the millennial workforce in the New Normal in First Philippine Industrial Park?

$>$ Does the level of work-related stress singly or in combination significantly affect employee engagement among the millennial workforce in the New Normal in First Philippine Industrial Park?

$>\quad$ Based on the findings of the study, what action plan may be proposed?

\subsection{Hypotheses}

The following hypotheses were tested for their significance.

$>\mathrm{H}_{0} 1$ : Work-Related Stress has no significant relationship on Employee Engagement among the Millennial Workforce in the New Normal.

$>\quad \mathrm{H}_{0} 2$ : Work-Related Stress does not affect Employee Engagement among the Millennial Workforce in the New Normal.

\subsection{Scope and Delimitations}

This study focused on determining current levels of work-related stress and employee engagement and find out any significant effect. The study was conducted with the locator employees of First Philippine Industrial Park, Tanauan City, Batangas. The respondents of the study will consist of millennials employees who were born from 1981 to 1996, from which the sample was obtained. The study will be done during the School Year of 20202021. The profile of the respondents included in the study was limited to the demographic profile, level of stress, and level of employee engagement. All other variables in the subject's profile were beyond the scope of this 
Work-related stress and employee engagement among millennial workforce in the new normal

study. Data will be obtained from the respondents through the use of online surveys and questionnaires.

\subsection{Significance of the Study}

This research may be applicable to the labor industry in providing better management of work-related stress and employee engagement among millennial workforce in the new normal. Hence, the researcher considers the following to be the primary beneficiaries of this study:

Millennial Workforce. This study will gather the view of the employees, implement a sound statistical treatment and yield an accurate result that will best represent the general conditions of the workforce in this time of the new normal in terms of work-related stress and employee engagement. This way, their collective voice will be heard in the form of reliable research which can later be a basis on how to improve their current work conditions.

Human Resource Department. The findings of this study will be instrumental to Human Resources by providing solid literature to serve as a reference or benchmarking resource that can be used as a supporting document in proposing programs to strengthen employee engagement based on the actual work situation during the COVID-19 pandemic.

Company's Top Management. The findings of this study will be useful for the company's management to understand the current situation that the workforce is facing. This will enable them to extend their support in addressing the types of concern that may arise in the study in particular to work-related stress and employee engagement.

Future Researchers. The results of the study may be valuable to future researchers of Industrial/Organizational Psychology who are interested in knowing how the COVID-19 pandemic has affected some aspects of the workplace, particularly in stress and employee engagement.

\subsection{Definition of Terms}

The following terms and concepts were operationally defined for further clarity and understanding of the reader:

Absorption. It denotes the extent of engrossment of an employee towards work.

Dedication. It refers to the level of commitment of an employee to perform responsibilities at work.

Employee Engagement. It refers to the human resource concept used to describe an employee's state of enthusiasm to do his best in his job and to stay at his job.

Job Demand. It refers to the aspect of physical, intellectual, psychological, and behavioral requirements expected to be fulfilled in the performance of a job.

Job Control. It refers to the amount of freedom that an employee exercises during job execution, as well as, in making work-related decisions.

Millennial. It is a term used as a generational cohort for people born between the period of 1981 to 1996.

New Normal. It is a term used to define the new standard of living to adjust to the changes brought about by the pandemic.

Vigor. It stands for the enthusiasm that an employee feels towards work.

Workforce. It denotes the collective term for people who are available to work or are working. 
Work-related Stress. It is a form of psychosocial stress which arises in the performance of a job.

Workplace Support. It refers to physical, intellectual, psychological, or emotional reinforcement given by people from the workplace, such as from superiors and colleagues, to be able to carry out duties and responsibilities at work successfully.

\section{Review of related literature}

\subsection{Millennial Workforce}

Chillakuri and Mogili (2018) presented a study that deduced a strategy in leading the millennials to fully maximize their talent in the workplace. Millennials involve themselves in conversations with the same age and group who think alike. They also express very little loyalty as compared to the previous generations, thus, they feel underutilized despite having greater potential to do more. Plamann (2019) cited Lu and Gursoy (2016) that despite the many factors causing the increase in turnover rates, the growth of the millennial population in the workforce is potentially taking the most percentage. Studies revealed that compared to any generation, the millennials are not afraid to leave a job and they are usually being first to feel burnout at work. Because burnout is one of the predictors of why employees decide to leave a job and millennials are more likely to experience this than other generations, it may be linked to the high turnover rates among millennials. Additionally, Rivers (2018) deduced seven factors that affect millennial job-hopping which include competitive compensation, job enjoyment, opportunities for professional growth, supportive work environment, reasonable free/flex time, finding their niche, and excellent benefits. Based on these factors, the Millennials' job-hopping theory spells out their decision-making process and reasons for job-hopping. Positive social change transpires when millennials achieve job satisfaction because it increases loyalty and organizational commitment and reduces stress, which results in a decreased turnover and increased economic stability for the millennials and their organizations.

In an online article published by Jobstreet in 2019, millennials take up $61 \%$ of the PH workforce. This data was gathered from their Law of Attraction survey which was participated by over 18,000 Filipino job-seekers from different industries. However, the Millennials have been stereotyped as "notorious job hoppers" and labeled as "impatient", "unfocused", "entitled", "easily dissatisfied", and "the most difficult to manage and retain." These negative impressions seem to exist due to the little understanding and awareness of the senior members of the organization towards this new generation. Similarly, Separa et al. (2020) claimed that Filipino millennials are motivated at work by having autonomy. They are confident that they possess good work habits and that they have an amicable relationship with their seniors and colleagues. They also prefer working in the Philippines, rather than abroad, if given a competitive compensation package. Furthermore, Chopra and Bhilare (2020) mentioned that millennials are leaned towards strong mentors who will guide them and lay out a plan for their growth. They also value rewards and having their ideas recognized, as well as, exploring cross-functional roles. Being aware of these expectations can be helpful for organizations in formulating strategies for recruitment, onboarding, and retention policies.

\subsection{Millennial Workforce during Covid-19 Pandemic}

In an ongoing social listening project compiled by Lajoie et al. (2020) involving Millennial workers in Ireland, initially collected stories revealed that respondents face different aspects of uncertainties at this time of the COVID-19 global health crisis. Rutten and Becker (2020) deduced that Millennials see their relationship with their leader be motivational during the COVID-19 pandemic if: the leader was able to meet basic emotional needs, portray themselves as a vulnerable human being within the relationship, display the ability to see a silver lining in the situation and express it to the employee and communicate in a way that the Millennials feel acceptable.

Meanwhile, Anicich et al. (2020) investigated the process of psychological recovery of full-time employees

58 Consortia Academia Publishing (A partner of Network of Professional Researchers and Educators) 
during the two weeks at the onset of the Coronavirus pandemic (COVID-19) based on autonomy restoration theory. The results of the study proved their hypothesis that recovery of impaired autonomy starts immediately even as the stressor is ongoing, in contrast to past researches that say that employees may recover their autonomy years after the stressor has gone. Findings suggest that autonomy restoration was manifested even while the pandemic has worsened. The study claimed that the pandemic initially threatened employee autonomy, but the employees began to recover their sense of autonomy almost immediately.

Was this resiliency because at this time of the pandemic, the millennial generation takes up the majority of the workforce?

The Deloitte Global Millennial Survey 2020 recognized that the millennials and Gen Zs hold the key to creating a "better normal". Deloitte research reveals "resilient generations." During this time of pandemic which brought a lot of uncommon circumstances in health and economy, the millennials and Gen Zs showed determination and a vision to make a better future. This pandemic has strengthened their desire to help create positive change in the communities and around the world. They strive to encourage businesses and governments to make a strong commitment to society with the priority of people over profits and sustaining the environment. The world that comes after the COVID-19 pandemic surely will be distinct and most likely be aligned with the ideals that millennials and Gen Zs. They have witnessed how fast the earth can restore itself, how swift businesses can transform, and how inventive and collaborative people can get. They believe that a post-pandemic society is a lot better than the one before and they are strongly motivated to make it happen.

Building upon The Deloitte Global Millennial Survey 2020, Parmelee (2020) wrote an article presenting the highlights of the survey. According to her, there is a potential silver lining to the disruption caused by the COVID-19 pandemic since the anxiety levels of millennial respondents fell eight points from $44 \%$ on the follow-up survey compared to the first one and the millennials developed a stronger sense of individual responsibility due to the pandemic. Similarly, Codd (2020) mentioned that even before the pandemic, a substantial number of millennial and Gen $\mathrm{Z}$ workers were experiencing stress and anxiety most of the time. However, in the succeeding pulse survey conducted between April and May 2020, stress levels fell for both generations which may be caused by the emergence of work-from-home options and a sudden slow-down of life in general.

\subsection{Work-Related Stress}

Glazer and Liu (2017) mentioned that the field of Industrial and Organizational Psychology regards work stress as the process of a person's interaction with various facets of the work environment, job design, and work conditions in the organization. According to World Health Organization, work-related stress comes in different situations at work and most often becomes worse when the employees do not feel support from superiors and colleagues and when they feel that they do not have control over work-related matters. Stress is being used interchangeably with pressure or challenge and is being used as an excuse for bad management practice, i.e. when an employee experience stress, it may be construed as not being competent enough to cope with pressure or challenges at work.

Coppel (2017) cited that in a survey conducted through the Workplace Stress Study of more than 1,000 full-time office workers, results show that $52 \%$ of employees overall feel that they are more stressed than they were a year ago. Similarly, Yunita and Saputra (2019) examined the impact of work mutations on work stress, as well as, on employee performance. The results of the study revealed that changes in the workplace have a negative impact on work stress, as well as, work stress negatively affects performance. Furthermore, work stress links the impact of work mutations on employee performance. The findings also unveiled differences in handling work mutations across genders. Male employees are found to be calmer and not stressed in coping with work mutations compared to female employees. De Sio, et al. (2018) mentioned that when employees perceive psychosocial risks in the workplace, it raises the tendency for them to develop work-related stress, with the 
female workers more vulnerable than male workers.

Likewise, Malhotra (2019) mentioned that excessive stress for a long duration leads to workplace burnout and may cause different physical illnesses. It can also affect mental health because it may be linked to a higher risk of depression, anxiety, and insomnia. Employees who usually work overtime are at a serious risk of burnout which can cause fatigue, mood swings, irritability, and a diminished level of work performance. This has a bad implication for employers because according to Harvard Business Review, the psychological and physical problems of burned-out employees have an estimated cost of $\$ 125$ billion to $\$ 190$ billion a year in healthcare spending in the United States. Furthermore, Ippoliti (2017) deduced that work-related stress generally causes a negative psychological and physical impact upon several interrelated variables damaging the health of the employees and the organization itself. Additionally, LeBlanc and Marques (2019) cited Melchior, et al. (2007) for a study that revealed that younger people who regularly deal with heavy workloads and extreme time pressure on the job are at risk to be diagnosed with major depressive disorder and generalized anxiety disorder.

In the meantime, Hessels, Rietveld and van der Zwan (2017) investigated the differences in work-related stress between the self-employed and wage workers based on the Job Demand-Control (JDC) model. Given the premise that the JDC model suggests that job demand increases work-related stress and job control reduces it, the findings of the study confirmed that job control fully mediates the negative relationship between self-employment and work-related stress. Similarly, Basu, Qayyum and Mason (2016) claimed that some interventions can attack stressors in the workplace such as: reduce demand and increase workers' control over their job, improve managerial support, establish better working relationships and make workers' feel more valued for their efforts. Comparably, Sedat Kula (2016) claimed that there is an indirect causal effect of both organizational and operational stress on job satisfaction via supervisor support as a mediator. Moreover, Stankevičiūtè and Savanevičienė (2019) concluded that a workplace where sustainable Human Resource Management is shown and felt by the people is an organization where employees experience less work-related stress, work-family conflict, and burnout.

\subsection{Employee Engagement}

Mazzei (2018) defined employee engagement as a distinctive concept that involves an individual characteristic demonstrating a mindset regarding enthusiasm which in certain situations leads to a persistent psychological state of cognitive absorption in one's work, emotional dedication, and vigor, a physical-energetic component. Similarly, Clack (2020) stated that employee engagement is one of the most important leads to organizational success due to its inevitable interrelation with other essential factors such as employee retention, morale, and productivity. When employees are not engaged at work, companies lose a lot of money on attendance issues, low productivity, and attrition. Additionally, Khan, Zahra, Bilal, Sufyan and Naz (2021) suggested that demands in the working environment pose a negative effect on job engagement and organizational commitment, and a positive effect between job engagement and organizational commitment. Moreover, job engagement takes part in the conciliation between job demand and organizational commitment. Likewise, Hoppe, Toker, Schachler, and Ziegler (2016) studied the effect of change in supervisor support and job control on change in vigor. The findings revealed that change in job control was related to change in vigor

Kerdpitak and Jermsittiparsert (2020) suggested that Human resources must foster best practices because it engages the employees in the workplace and improves the competitive advantage of the companies through employee training, learning practices, employee selection, and competitive advantage. Also, Sivapragasam and Raya (2017) established a statistical significance linking Human Resource Management practices and employee-level outcomes such as perceived efficacy, engagement, and employee well-being. Similarly, Larasati, Hasanati, and Istiqomah (2019) mentioned that companies that show concern and interest in their employees' personal life, as well as, work-life are found to positively affect the level of employee engagement to the company. Employee engagement characterized by dimensions such as vigor, dedication, and absorption is proven to have a positive impact on employee productivity. 
Work-related stress and employee engagement among millennial workforce in the new normal

Likewise, Saks (2019) revisited his 2006 study on antecedents and consequences of employee engagement and employed additional analyses including the Utrecht Work Engagement Scale (UWES). The findings of the study revealed that skill variety is the main job characteristic that determines employee engagement. After the analysis of the UWES results, it was found that "job characteristics and perceived organizational support are significant predictors of work engagement, and work engagement predicts job satisfaction, organizational commitment, organizational citizenship behavior and intentions to quit and mediates the relationship between the antecedents and the consequences". In the same manner, Meintjes and Hofmeyr (2018) also concluded that perceived organizational support bears an impact on employee engagement in the workplace through the use of UWES.

Additionally, Baran and Sypniewska (2020) declared that their research findings revealed, through a structural equation model, that people-oriented management and active participation or co-deciding by employees are significant predictors for work engagement. As far as the dimensions of engagement are concerned (i.e., vigor, dedication, and absorption), their values are considered directly proportionate, thus, when one increases, the other one also increases. People-oriented management renders active participation. Then, active participation translates into engagement in all three dimensions. Kadiresan et al. (2019) stated that employees who are affected by work-related stress have reduced engagement levels in the organization. While, $\mathrm{Xu}$ et al. (2017) claimed that attending to the psychological capital of both employees and their leaders in the organization can increase employee engagement. Moreover, Van Mol et al. (2018) concluded that work engagement counterbalances work-related stress reactions.

\subsection{Synthesis}

All the above-mentioned reviewed literature and studies served as a reference for the different variables of the study. These materials support the researcher in her discussion to shed light on the postulation used in this study. Evidently, Chillakuri and Mogili (2018), Plamann (2019), and Rivers (2018) postulated that the millennial generation differs from the previous generations in terms of workplace behavior, outlook, perspective, motivation, and loyalty, as well as, reason for leaving and job satisfaction. Additionally, Anicich, et al. (2020) and the Deloitte Global Millennial Survey 2020, revealed that the millennial workforce displayed a marked resiliency in terms of recovering through the pandemic, considering them as a "resilient generation" holding the key to a better normal. Meanwhile, Codd (2020) mentioned that even before the pandemic, a substantial number of millennial and Gen $\mathrm{Z}$ workers were experiencing stress and anxiety most of the time. Malhotra (2019), Ippoliti (2017), and LeBlanc and Marques (2019), cited the negative effects of prolonged work-related stress to physical and mental health, as well as, to the health of the organization itself. Whereas, Basu, et al. (2016) claimed that some interventions can attack stressors in the workplace such as: reduce demand and increase workers' control over their job, improve managerial support, establish better working relationships and make workers' feel more valued for their efforts.

Moreover, Stankevičiūtè and Savanevičienè (2019) concluded that a workplace where sustainable Human Resource Management is shown and felt by the people is an organization where employees experience less work-related stress, work-family conflict, and burnout. Noticeably, Larasati et al. (2019), Saks (2019), and Hofmeyr (2018) employed the dimensions of employee engagement namely vigor, dedication, and absorption through the use of the Utrecht Work Engagement Scale (UWES) to examine the interrelation of employee engagement to other aspects in the workplace. In conclusion, Kerdpitak and Jermsittiparsert (2020) and Sivapragasam and Raya (2017) featured the important role that Human Resources Management plays in the fulfillment of employee engagement and that it can neutralize work-related stress as stated by Van Mol et al. (2018).

\section{Methodology}

Research Design - The researcher used the causal research, non-experimental method. Causal research is 
also known as explanatory research. As the term implies, it is used to investigate the nature of cause-and-effect relationships among variables. On the other hand, the non-experimental method is a design wherein the researcher does not manipulate the independent variable.

Research Locale - The study was conducted in locator companies of First Philippine Industrial Park (FPIP), Tanauan City, Batangas. This locale is considered given the familiarity of the researcher to FPIP, being her previous workplace. It is beneficial to conduct a study on how companies in FPIP can formulate an engagement strategy to deal with their millennial employees to bring out their best potential, based on the work-related stress that millennials experience, especially at the time of the new normal. The study will be conducted during the School Year of 2020 - 2021.

Population and Sampling - The researcher used Cluster Sampling. Frey (2018) defined cluster sampling as a probability sampling technique in which all population elements are categorized into mutually exclusive and exhaustive groups called clusters. Clusters are selected for sampling, and all or some elements from selected clusters comprise the sample. This method is typically used when natural groups exist in the population (e.g., schools or counties) or when obtaining a list of all population element is impossible or impractically costly". The sample size yielded an achieved statistical power of .999 based on the .15 effect size of a two-tailed multiple regression analysis of 5 predictor variables, as per computation using G-Power.

Respondents of the Study - The respondents of the study were comprised of millennial employees (born between the periods of 1981 to 1996) from locator companies of First Philippine Industrial Park.

Table A

Distribution of Respondents of the Study

\begin{tabular}{|c|c|c|}
\hline Company & Population & Sample Size \\
\hline $\mathrm{A}$ & 260 & 98 \\
\hline B & 1,200 & 217 \\
\hline $\mathrm{C}$ & 180 & 56 \\
\hline D & 80 & 10 \\
\hline E & 120 & 22 \\
\hline $\mathrm{F}$ & 100 & 15 \\
\hline G & 100 & 19 \\
\hline \multicolumn{2}{|c|}{ TOTAL } & 427 \\
\hline
\end{tabular}

Data Gathering Procedure - The researcher sent a letter of request via e-mail to the administrative office of the First Philippine Industrial Park to obtain permission in conducting the study with the employees of the locator companies of the park. Upon the approval to conduct the study, the researcher started the data gathering. The researcher plotted the standardized questionnaires of the Job Stress Scale and the 17-item Utrecht Work Engagement Scale (UWES-17) into an online form questionnaire to limit physical contact with the respondents in accordance with the implemented social distancing due to the COVID-19 pandemic.

Instrument - The researcher used standardized instruments to obtain relevant information for the study. To measure the level of work-related stress, the short version of the Job Stress Scale is used. This scale used questions that are based on the Job Demand-Control-Support model and uses a 4-point Likert Scale with the options: Often, Sometimes, Seldom, and Never/Almost Never. The questionnaire is divided into three categories to measure different indicators of job stress: (a) Demands, 5 questions; (b) Control, 6 questions; and (c) Support, 6 questions.

To measure the Employee Engagement aspect of the respondents, the Utrecht Work Engagement Scale (UWES) by Schaufeli and Bakker (2004) was utilized. This consists of 17 statements of situational items that the respondents will respond to through a 6-point Likert scale using the options such as Often, Always, Very often, Sometimes, Rarely, and Almost never. As explained by Schaufeli and Bakker (2004) the mean scale score of the three UWES subscales is computed by adding the scores on the particular scale and dividing the sum by the

62 Consortia Academia Publishing (A partner of Network of Professional Researchers and Educators) 
number of items of the subscale involved. A similar procedure is followed for the total score. Hence, the UWES yields three subscale scores and/or a total score that ranges between 0 and 6 .

For the Job Stress Scale, the verbal interpretation "Never" has an equivalent interpretation of "Very Low", the verbal interpretation "Seldom" has an equivalent interpretation of "Low", the verbal interpretation "Sometimes" has an equivalent interpretation of "High", and the verbal interpretation "Often" has an equivalent interpretation of "Very High". On the other hand, for the Utrecht Work Engagement Scale (UWES), the verbal interpretation and equivalent interpretation are as follows: Always - Extremely High, Very Often - Very High, Often - High, Sometimes - Neither High nor Low, Rarely - Low, Almost Never - Very Low, and Never Extremely Low.

Ethical Consideration - The ethical concerns were followed by the researcher as those were taken into account throughout this paper. Consent was asked wherein confidentiality will be assured. All the necessary details were explained by the researcher for them to understand their role upon the completion of the study. Information personal to the co-researchers was assured to have its confidentiality.

Treatment of Quantitative Data - Statistical treatment provides a systematic and acceptable approach in answering the research problems. The following were the statistical techniques employed in the treatment of the data gathered. The Percentage Formula was used for figure representation among collected data. The Mean Formula was used to determine the level of Work-Related Stress and Employee Engagement among the Millennial Workforce of the locator companies in First Philippine Industrial Park. To establish any significant effect of Work-Related Stress on Employee Engagement, Multiple Regression will be employed. To interpret the results of the level of Work-Related Stress and level of Employee Engagement, Equivalent Interpretation was employed based on the Likert Scale's Verbal Interpretation from the standard questionnaires.

\section{Presentation, analysis, and interpretation of data}

Problem Number 1: What is the level of work-related stress among the millennial workforce in the New Normal in First Philippine Industrial Park in terms of Demand, Control, and Support?

\subsection{Work-related Stress in terms of Demand}

Table 1.1 shown the level of work-related stress among the millennial workforce in the New Normal in First Philippine Industrial Park in terms of Demand. The general assessment was $\mathbf{1 . 7 1}$ which was verbally interpreted as "Often" and has an equivalent interpretation of "Very High". The indicator "Do you have enough time to do everything?" has the highest computed mean of 1.82 which was verbally interpreted as "Sometimes" with an equivalent interpretation of "High", while the indicator "Do you have to work very intensively?" has the least computed mean of 1.64 and was verbally interpreted as "Often" and has an equivalent interpretation of "Very High".

\section{Table 1.1}

Level of work-related stress among the millennial workforce in terms of demand

\begin{tabular}{|c|c|c|c|}
\hline Indicators in terms of Demand & $\mathrm{M}$ & VI & EI \\
\hline Do you have to work very fast? & 1.66 & Often & Very High \\
\hline Do you have to work very intensively? & 1.64 & Often & Very High \\
\hline Does your work demand too much effort? & 1.69 & Often & Very High \\
\hline Do you have enough time to do everything? & 1.82 & Sometimes & High \\
\hline Do your work often involve conflicting demands? & 1.77 & Sometimes & Very High \\
\hline GENERAL ASSESSMENT & 1.71 & Often & Very High \\
\hline
\end{tabular}

It can be concluded that Demand causes very high work stress among the millennial workforce in the New Normal in First Philippine Industrial Park. It was evident that working intensively gives the workforce very high 
Vigo, E. M. A.

stress. The association of intense work resulting to very high stress was discussed by LeBlanc and Marques (2019) citing Melchior, et al. (2007) with a study that revealed that younger people who regularly deal with heavy workloads and extreme time pressure on the job are at risk to be diagnosed with major depressive disorder and generalized anxiety disorder as a result of work stress.

\subsection{Work-related Stress in terms of Control}

Table 1.2 showed the level of work-related stress among the millennial workforce in the New Normal in First Philippine Industrial Park in terms of Control. The general assessment was $\mathbf{1 . 7 7}$ which was verbally interpreted as "Sometimes" with an equivalent interpretation of "High". The indicator "Do you have a choice in deciding HOW you do your work?" has the highest computed mean of 1.89 which was verbally interpreted as "Sometimes" with an equivalent interpretation of "High", while the indicator "Do you have to do the same thing over and over again?" has the least computed mean of 1.66 and was verbally interpreted as "Often" with an equivalent interpretation of "Very High".

\section{Table 1.2}

Level of work-related stress among the millennial workforce in terms of control

\begin{tabular}{|c|c|c|c|}
\hline Indicators in terms of Control & $\mathrm{M}$ & VI & EI \\
\hline $\begin{array}{l}\text { Do you have the possibility of learning } \\
\text { new things through your work? }\end{array}$ & 1.75 & Sometimes & High \\
\hline $\begin{array}{l}\text { Does your work demand a high level } \\
\text { of skill or expertise? }\end{array}$ & 1.70 & Often & Very High \\
\hline $\begin{array}{l}\text { Does your job require you to take the } \\
\text { initiative? }\end{array}$ & 1.87 & Sometimes & High \\
\hline $\begin{array}{l}\text { Do you have to do the same thing over } \\
\text { and over again? }\end{array}$ & 1.66 & Often & Very High \\
\hline $\begin{array}{l}\text { Do you have a choice in deciding } \\
\text { HOW you do your work? }\end{array}$ & 1.89 & Sometimes & High \\
\hline $\begin{array}{l}\text { Do you have a choice in deciding } \\
\text { WHAT you do at work? }\end{array}$ & 1.75 & Sometimes & High \\
\hline GENERAL ASSESSMENT & 1.77 & Sometimes & High \\
\hline
\end{tabular}

It can be concluded that high levels of Control cause high work stress among the millennial workforce in the New Normal in First Philippine Industrial Park. It was evident that doing the same thing over and over again gives the workforce very high stress. To support this finding, Saks (2019) revealed that skill variety is the main job characteristic that determines employee engagement. In addition, the World Health Organization mentioned that work-related stress comes in different situations at work and most often becomes worse when the employees feel that they do not have control over work-related matters. In this context, the lack of control in the workplace is characterized by doing the same thing over and over again through repetitive tasks.

\subsection{Work-related Stress in terms of Support}

Table 1.3 shown the level of work-related stress among the millennial workforce in the New Normal in First Philippine Industrial Park in terms of Support. The general assessment was $\mathbf{3 . 2 5}$ which was verbally interpreted as "Seldom" and has an equivalent interpretation of "Low". The indicator "We get on well with each other where I work." has the highest computed mean of 3.38 which was verbally interpreted as "Never" an equivalent interpretation of "Very Low", while the indicator "There is a calm and pleasant atmosphere where I work" has the least computed mean of 3.03 and was verbally interpreted as Seldom and an equivalent interpretation of "Low". It can be concluded that Support which is seldom experienced causes low levels of work stress among the millennial workforce in the New Normal in First Philippine Industrial Park. It was evident that seldom having a calm and pleasant atmosphere at work only gives the workforce low-level stress.

The results imply that the millennial workforce do not get easily affected by low levels of support, including not having a good work atmosphere. This can be explained by the study of Chopra and Bhilare (2020) pointing 
Work-related stress and employee engagement among millennial workforce in the new normal

out that millennials are leaned towards strong mentors who will guide them and lay out a plan for their growth. They also value rewards and having their ideas recognized, as well as, exploring cross-functional roles. In summary, in terms of workplace support, the millennials place greater importance on their mentor's guide compared to work atmosphere. Comparably, Sedat Kula (2016) claimed that there is an indirect causal effect of both organizational and operational stress on job satisfaction via supervisor support as a mediator.

Table 1.3

Level of work-related stress among the millennial workforce in terms of support

\begin{tabular}{|c|c|c|c|}
\hline Indicators in terms of Support & $\mathrm{M}$ & VI & EI \\
\hline There is a calm and pleasant atmosphere where I work. & 3.03 & Seldom & Low \\
\hline We get on well with each other where I work. & 3.38 & Never & Very Low \\
\hline My co-workers support me. & 3.28 & Never & Very Low \\
\hline The others understand if I have a bad day. & 3.23 & Seldom & Low \\
\hline I get on well with my superiors. & 3.36 & Never & Very Low \\
\hline I enjoy working with my co-workers. & 3.20 & Seldom & Low \\
\hline GENERAL ASSESSMENT & 3.25 & Seldom & Low \\
\hline
\end{tabular}

Problem Number 2. What is the level of employee engagement among the millennial workforce in the New Normal in First Philippine Industrial Park in terms of Vigor, Dedication, and Absorption?

\subsection{Employee Engagement in terms of Vigor}

Table 2.1 shown the level of employee engagement among the millennial workforce in the New Normal in First Philippine Industrial Park in terms of Vigor. The general assessment was 4.38 which was verbally interpreted as "Very Often" with an equivalent interpretation of "Very High". The indicator "At my work, I always persevere, even when things do not go well" has the highest computed mean of 4.85 which was verbally interpreted as Very Often, and an equivalent interpretation of Very High, while the indicator "At my work, I feel bursting with energy" has the least computed mean of 3.92 and was verbally interpreted as Often with an equivalent interpretation of Very High.

Table 2.1

Level of employee engagement among the millennial workforce in terms of vigor

\begin{tabular}{lcc}
\hline \multicolumn{1}{c}{ Indicators in terms of Vigor } & M & VI \\
\hline At my work, I feel bursting with energy & 3.92 & Often \\
At my job, I feel strong and vigorous & 4.20 & Often \\
When I get up in the morning, I feel like going to work & 4.31 & Often \\
I can continue working for very long periods at a time & 4.48 & Very Often \\
At my job, I am very resilient, mentally & 4.51 & Very Often \\
At my work I always persevere, even when things do not go well & 4.85 & Very Often \\
\hline
\end{tabular}

Legend: 5.16 - 6.00 Always / Extremely High, 1.72 - 2.57 Rarely / Low, 4.30 - 5.15 Very Often / Very High, 0.86 - 1.71 Almost Never / Very Low, 3.44 - 4.29 Often / High, 0.00 - 0.85 Never / Extremely Low, 2.58 - 3.43 Sometimes / Neither High nor Low.

It can be concluded that Vigor contributes to very high employee engagement among the millennial workforce in the New Normal in First Philippine Industrial Park. It was evident that persevering even when things do not go well at work makes up a workforce with very high engagement. In support to this, Larasati et al. (2019) mentioned that employee engagement characterized by dimensions such as vigor is proven to have a positive impact on employee productivity. This explains why the majority of respondents said that they always persevere at work even when things do not go well.

\subsection{Employee Engagement in terms of Dedication}

Table 2.2 shown the level of employee engagement among the millennial workforce in the New Normal in First Philippine Industrial Park in terms of Dedication. The general assessment was 4.77 which was verbally interpreted as "Very Often" and has an equivalent interpretation of "Very High". 


\section{Table 2.2}

Level of employee engagement among the millennial workforce in terms of dedication

\begin{tabular}{|c|c|c|c|}
\hline Indicators in terms of Dedication & M & VI & EI \\
\hline I find the work that I do full of meaning and purpose & 4.70 & Very Often & Very High \\
\hline I am enthusiastic about my job & 4.57 & Very Often & Very High \\
\hline My job inspires me & 4.56 & Very Often & Very High \\
\hline I am proud of the work that I do & 5.10 & Very Often & Very High \\
\hline To me, my job is challenging & 4.93 & Very Often & Very High \\
\hline GENERAL ASSESSMENT & 4.77 & Very Often & Very High \\
\hline
\end{tabular}

Legend: 5.16 - 6.00 Always / Extremely High, 1.72 - 2.57 Rarely / Low, 4.30 - 5.15 Very Often / Very High, 0.86 - 1.71 Almost Never / Very Low, 3.44 - 4.29 Often / High, 0.00 - 0.85 Never / Extremely Low, 2.58 - 3.43 Sometimes / Neither High nor Low.

The indicator "I am proud of the work that I do" has the highest computed mean of 5.10 which was verbally interpreted as Very Often, with an equivalent interpretation of Very High, while the indicator "My job inspires $m e$ " has the least computed mean of 4.56 and was verbally interpreted as Very Often and an equivalent interpretation of Very High. It can be concluded that Dedication contributes to very high employee engagement among the millennial workforce in the New Normal in First Philippine Industrial Park. It was evident that feeling proud of the work they do at work makes the workforce engaged very often. In support to this, Saks (2019) revisited his 2006 study on antecedents and consequences of employee engagement and employed additional analyses including the Utrecht Work Engagement Scale (UWES). After the analysis of the UWES results, one of the findings revealed that work engagement predicts organizational commitment, or in this context, dedication.

\subsection{Employee Engagement in terms of Absorption}

Table 2.3 shown the level of employee engagement among the millennial workforce in the New Normal in First Philippine Industrial Park in terms of Absorption.

Table 2.3

Level of employee engagement among the millennial workforce in terms of absorption

\begin{tabular}{lcc}
\hline \multicolumn{1}{c}{ Indicators in terms of Absorption } & M & VI \\
\hline Time flies when I'm working & 5.05 & Very Often \\
Often & Very High \\
When I am working, I forget everything else & 3.38 & Very Often \\
around me & 4.38 & Very Often \\
I feel happy when I am working intensely & 4.34 & Often \\
I am immersed in my work & 3.80 & Often \\
I get carried away when I'm working & 3.69 & Often \\
It is difficult to detach myself from my job & 4.11 & Very High \\
\hline
\end{tabular}

Legend: 5.16 - 6.00 Always / Extremely High1.72 - 2.57 Rarely / Low, 4.30 - 5.15 Very Often / Very High, 0.86 - 1.71 Almost Never / Very Low, 3.44 - 4.29 Often / High, 0.00 - 0.85 Never / Extremely Low, 2.58 - 3.43 Sometimes / Neither High nor Low.

The general assessment was $\mathbf{4 . 1 1}$ which was verbally interpreted as "Often" with an equivalent interpretation of "High". The indicator "Time flies when I'm working” has the highest computed mean of 5.05 which was verbally interpreted as Very Often and an equivalent interpretation of Very High, while the indicator "When I am working, I forget everything else around me" has the least computed mean of 3.38 and was verbally interpreted as Often and has an equivalent interpretation of High. It can be concluded that Absorption contributes to High employee engagement among the millennial workforce in the New Normal in First Philippine Industrial Park. It was evident that the feeling that time flies at work makes up a workforce that has very high engagement. This can be explained when Mazzei (2018) defined employee engagement as a distinctive concept that involves an individual characteristic demonstrating a mindset regarding enthusiasm which in certain situations leads to a persistent psychological state of cognitive absorption in one's work, in this context, having a feeling that time flies at work.

Problem Number 3: Is there any significant relationship between work-related stress and employee engagement among the millennial workforce in the New Normal in First Philippine Industrial Park? 
As shown in Table 3, the $\mathrm{r}$ values of all the variables were interpreted as with negligible negative to very weak negative correlation as to correlate work-related stress specifically Demands and employee engagement specifically Vigor and Dedication, and the computed probability values were lesser than the level of significant $(p<0.05)$; thus, the null hypothesis is rejected. The result has shown that there is a significant relationship between the dependent and independent variables.

On the other hand, the computed probability value of Demand and Absorption was greater than the level of significance $(p<0.05)$; thus, the null hypothesis is accepted. The result has shown that there is no significant relationship between the dependent and independent variables. It can be concluded that work-related stress specifically Demand has a significant relationship with employee engagement specifically Vigor and Dedication while Demand has no significant relationship with Absorption. In support to this, Malhotra (2019) mentioned that work stress for a long duration leads to workplace burnout. Employees who usually work overtime are at a serious risk of burnout which can cause fatigue, mood swings, irritability, and a diminished level of work performance, essentially relating to Vigor and Dedication. On the other hand, the findings that Demand has no significant relationship with Absorption contradicts the study of Khan et al. (2021) which suggested that demands in the working environment pose a negative effect on employee engagement which includes Absorption as one of its components.

Also shown in Table 3, the r values of Control were interpreted as with negligible negative to very weak negative correlation as to correlate work-related stress and employee engagement specifically Dedication and Absorption, and the computed probability values were lesser than the level of significance $(p<0.05)$; thus, the null hypothesis is rejected. The result has shown that there is a significant relationship between the dependent and independent variables.

Table 3

Test of significant relationship between the work-related stress and employee engagement

\begin{tabular}{llllll}
\hline \multicolumn{1}{c}{ Work-Related Stress } & Employee Engagement & r value & P-value & \multicolumn{1}{c}{ Remarks } & Decision \\
\hline Demands & Vigor & $-.099^{*}$ & .040 & Significant & Reject $\mathrm{H}_{\mathrm{o}}$ \\
& Dedication & $-.210^{* *}$ & .000 & Significant & Reject $\mathrm{H}_{\mathrm{o}}$ \\
& Absorption & .020 & .682 & Not Significant & Accept $\mathrm{H}_{\mathrm{o}}$ \\
\hline Control & Vigor & -.007 & .889 & Not Significant & Accept $\mathrm{H}_{\mathrm{o}}$ \\
& Dedication & $-.258^{* *}$ & .000 & Significant & Reject $\mathrm{H}_{\mathrm{o}}$ \\
& Absorption & $.096^{*}$ & .049 & Significant & Reject $\mathrm{H}_{\mathrm{o}}$ \\
\hline Support & Vigor & $-.105^{*}$ & .030 & Significant & Reject $\mathrm{H}_{\mathrm{o}}$ \\
& Dedication & -.073 & .134 & Not Significant & Accept $\mathrm{H}_{\mathrm{o}}$ \\
& Absorption & $-.126^{* *}$ & .009 & Significant & Reject $\mathrm{H}_{\mathrm{o}}$ \\
\hline$* *$
\end{tabular}

*Correlational at the level 0.05 (Two-tailed).

On the other hand, the computed probability value of Control and Vigor was greater than the level of significance $(p<0.05)$; thus, the null hypothesis is accepted. The result has shown that there is no significant relationship between the dependent and independent variables. It can be concluded that work-related stress specifically Control has a significant relationship with employee engagement specifically Dedication and Absorption while Control has no significant relationship with Vigor. In support to this, Baran and Sypniewska (2020) declared that their research findings revealed, through a structural equation model, that people-oriented management and active participation or co-deciding by employees are significant predictors for work engagement. As far as the dimensions of engagement are concerned (i.e., vigor, dedication, and absorption), their values are considered directly proportionate, thus, when one increases, the other one also increases. People-oriented management renders active participation. Then, active participation translates into engagement in all three dimensions. On the other hand, the findings that Control has no significant relationship with Vigor contradict the literature by Hoppe et al. (2016) which revealed that change in job control was related to change in vigor.

Moreover, Table 3 shown the $\mathrm{r}$ values of Support were interpreted as with negligible negative to very weak 
Vigo, E. M. A.

negative correlation as to correlate work-related stress and employee engagement specifically Vigor and Absorption, and the computed probability values were lesser than the level of significance $(p<0.05)$; thus, the null hypothesis is rejected. The result has shown that there is a significant relationship between the dependent and independent variables. On the other hand, the computed probability value of Support and Dedication was greater than the level of significance $(p<0.05)$; thus, the null hypothesis is accepted. The result has shown that there is no significant relationship between the dependent and independent variables. It can be concluded that work-related stress specifically Support has a significant relationship with employee engagement specifically Vigor and Absorption while Support has no significant relationship with Dedication.

In support to this, Saks' (2019) analysis of the UWES results found that "job characteristics and perceived organizational support are significant predictors of work engagement". In the same manner, Meintjes and Hofmeyr (2018) also concluded that perceived organizational support bears an impact on employee engagement in the workplace through the use of UWES. On the other hand, the findings that Support has no significant relationship with Dedication contradicts the findings of the study of Saks (2019) which mentioned that perceived organizational support predicts organizational commitment, contextually referred to as Dedication.

Problem Number 4: Does the level of work-related stress singly or in combination significantly affect employee engagement among the millennial workforce in the New Normal in First Philippine Industrial Park?

Table 4.1

Regression analysis on the impact of the work-related stress to employee engagement in terms of control

\begin{tabular}{|c|c|c|c|c|c|c|c|}
\hline \multirow[b]{2}{*}{ Model } & \multicolumn{2}{|c|}{ Unstandardized Coefficients } & \multirow{2}{*}{$\begin{array}{c}\text { Standardized } \\
\text { Coefficients } \\
\text { Beta }\end{array}$} & \multirow[b]{2}{*}{$\mathrm{T}$} & \multirow[b]{2}{*}{ Sig. } & \multirow[b]{2}{*}{ Remarks } & \multirow[b]{2}{*}{ Decision } \\
\hline & B & Beta & & & & & \\
\hline (Constant) & 5.411 & .452 & & 11.97 & .000 & & \\
\hline Demand & .011 & .106 & .005 & .100 & .921 & Not Significant & Accept $\mathrm{H}_{\mathrm{o}}$ \\
\hline Control & -.508 & .117 & -.217 & -4.33 & .000 & Significant & Reject $\mathrm{H}_{\mathrm{o}}$ \\
\hline Support & -.047 & .096 & -.025 & -.489 & .625 & Not Significant & Accept $\mathrm{H}_{\mathrm{o}}$ \\
\hline
\end{tabular}

As shown in Table 4.1, the Work-Related Stress particularly Control significantly impacts Employee Engagement among the Millennial Workforce in the New Normal in First Philippine Industrial Park in terms of Vigor. The generated probability value of efficiency was .000 which was less than the level of significance $(p<.05)$, thus the null hypothesis is rejected. Furthermore, their control negatively influences the level of engagement. Control accounts for a $50.8 \%$ decrease in the employee engagement of the millennials in terms of Vigor. The study revealed that the Work-Related Stress particularly Control significantly impacts the Employee Engagement Among the Millennial Workforce in the New Normal in First Philippine Industrial Park in terms of Vigor. In support to this, Basu et al. (2016) claimed that one of the interventions that can attack stressors in the workplace is to increase workers' control over their job. In addition, a study made by Hoppe et. al. (2016) revealed that change in job control was related to change in vigor.

\section{Table 4.2}

Regression analysis on the impact of the work-related stress to employee engagement in terms of dedication

\begin{tabular}{|c|c|c|c|c|c|c|c|}
\hline \multirow[t]{2}{*}{ Model } & \multicolumn{2}{|c|}{$\begin{array}{c}\text { Unstandardized } \\
\text { Coefficients }\end{array}$} & \multirow{2}{*}{$\begin{array}{c}\text { Standardized } \\
\text { Coefficients } \\
\text { Beta } \\
\end{array}$} & \multirow[t]{2}{*}{$\mathrm{T}$} & \multirow[t]{2}{*}{ Sig. } & \multirow[t]{2}{*}{ Remarks } & \multirow[t]{2}{*}{ Decision } \\
\hline & B & Beta & & & & & \\
\hline (Constant) & 5.189 & .474 & & 10.95 & .000 & & \\
\hline Demand & .201 & .112 & .091 & 1.80 & .073 & Not Significant & Accept $\mathrm{H}_{\mathrm{o}}$ \\
\hline Control & -.673 & .123 & -.270 & -5.48 & .000 & Significant & Reject $\mathrm{H}_{\mathrm{o}}$ \\
\hline Support & .133 & .101 & .065 & 1.32 & .188 & Not Significant & Accept $\mathrm{H}_{\mathrm{o}}$ \\
\hline
\end{tabular}

Dependent Variable: Dedication.

As shown in Table 4.2, the Work-Related Stress particularly Control significantly impacts the Employee Engagement among the Millennial Workforce in the New Normal in First Philippine Industrial Park in terms of Dedication. The generated probability value of efficiency was .000 which was less than the level of significance

68 Consortia Academia Publishing (A partner of Network of Professional Researchers and Educators) 
Work-related stress and employee engagement among millennial workforce in the new normal

$(p<.05)$, thus the null hypothesis is rejected. Furthermore, control accounts for a $.67 .3 \%$ decrease in the engagement level of the employees. The dedication of the employees is adversely affected by their stress level in terms of control. The study revealed that the Work-Related Stress particularly Control significantly impacts the Employee Engagement Among the Millennial Workforce in the New Normal in First Philippine Industrial Park in terms of Dedication. To support the findings, Mazzei (2018) cited that employee engagement is a unique concept that leads to emotional dedication at work in certain situations.

Table 4.3

Regression analysis on the impact of the work-related stress to employee engagement in terms of absorption

\begin{tabular}{|c|c|c|c|c|c|c|c|}
\hline \multirow[t]{2}{*}{ Model } & \multicolumn{2}{|c|}{$\begin{array}{l}\text { Unstandardized } \\
\text { Coefficients }\end{array}$} & \multirow{2}{*}{$\begin{array}{c}\text { Standardized } \\
\text { Coefficients } \\
\text { Beta }\end{array}$} & \multirow[t]{2}{*}{$\mathrm{T}$} & \multirow[t]{2}{*}{ Sig. } & \multirow[t]{2}{*}{ Remarks } & \multirow[t]{2}{*}{ Decision } \\
\hline & B & Beta & & & & & \\
\hline (Constant) & 5.374 & .361 & & 14.90 & .000 & & \\
\hline Demand & -.197 & .085 & -.120 & -2.32 & .021 & Significant & Reject $\mathrm{H}_{\mathrm{o}}$ \\
\hline Control & -.156 & .093 & -.084 & -1.67 & .095 & Not Significant & Accept $\mathrm{H}_{\mathrm{o}}$ \\
\hline Support & -.201 & .077 & -.132 & -2.62 & .009 & Significant & Reject $\mathrm{H}_{\mathrm{o}}$ \\
\hline
\end{tabular}

Dependent Variable: Absorption.

As shown in Table 4.3, the Work-Related Stress particularly Demand and Support significantly impacts the Employee Engagement among the Millennial Workforce in the New Normal in First Philippine Industrial Park in terms of Absorption. The generated probability value of efficiency was .000 which was less than the level of significance $(p<.05)$, thus the null hypothesis is rejected. Furthermore, demand alone accounts for a 19.7 decrease in the employee engagement of absorption while support alone accounts for $20.1 \%$ of its decrease. The study revealed that the Work-Related Stress particularly Demand and Support significantly impacts the Employee Engagement among the Millennial Workforce in the New Normal in First Philippine Industrial Park in terms of Absorption. In support to this, Reis et al. (2016) concluded that job demand, such as high levels of time pressure, may negatively affect employees' energy levels but still boost their absorption at work. Additionally, Caesens (2015) claimed that perceived organizational support is positively related to proactive behavior directed towards the organization.

Problem Number 5: Based on the findings of the study, what action plan may be proposed to manage work-related stress and improve employee engagement in the New Normal?

The proposed action plan

\begin{tabular}{|c|c|c|c|c|c|c|}
\hline $\begin{array}{c}\text { AREA OF } \\
\text { CONCERN }\end{array}$ & OBJECTIVES & $\begin{array}{c}\text { STRATEGIES/ } \\
\text { ACTIVITIES }\end{array}$ & $\begin{array}{c}\text { TIME } \\
\text { FRAME }\end{array}$ & $\begin{array}{c}\text { PERSONS } \\
\text { INVOLVED }\end{array}$ & $\begin{array}{c}\text { SOURCE OF } \\
\text { FUND }\end{array}$ & $\begin{array}{c}\text { SUCCESS } \\
\text { INDICATORS }\end{array}$ \\
\hline $\begin{array}{c}\text { Work-related } \\
\text { stress caused } \\
\text { by intensive } \\
\text { work }\end{array}$ & $\begin{array}{l}\text { To ensure that } \\
\text { workload is } \\
\text { manageable and } \\
\text { commensurate }\end{array}$ & $\begin{array}{c}\text { Coaching / } \\
\text { Mentoring } \\
\text { Performance } \\
\text { Management } \\
\text { Process Automation }\end{array}$ & $\begin{array}{l}\text { July } 2021 \text { - } \\
\text { August } 2021\end{array}$ & $\begin{array}{l}\text { Human } \\
\text { Resource } \\
\text { Immediate } \\
\text { Superior } \\
\text { Employees }\end{array}$ & HR Budget & $\begin{array}{c}95 \% \text { of the } \\
\text { employees have } \\
\text { been ensured to } \\
\text { have a manageable } \\
\text { and commensurate } \\
\text { workload }\end{array}$ \\
\hline $\begin{array}{l}\text { Work-related } \\
\text { stress caused } \\
\text { by doing the } \\
\text { same thing } \\
\text { over and over } \\
\text { again }\end{array}$ & $\begin{array}{l}\text { To ensure that } \\
\text { work tasks are } \\
\text { made to be } \\
\text { intellectually } \\
\text { stimulating and } \\
\text { make way to } \\
\text { utilize their } \\
\text { creativity }\end{array}$ & $\begin{array}{l}\text { Process Automation } \\
\text { Cross-skilling } \\
\text { Internal Hiring }\end{array}$ & $\begin{array}{c}\text { July } 2021 \text { - } \\
\text { December } \\
2021\end{array}$ & $\begin{array}{l}\text { Human } \\
\text { Resource } \\
\text { Immediate } \\
\text { Superior } \\
\text { Employees }\end{array}$ & $\begin{array}{c}\text { Department } \\
\text { Budget }\end{array}$ & $\begin{array}{l}95 \% \text { of the } \\
\text { employees have } \\
\text { attested that their } \\
\text { work tasks are } \\
\text { intellectually } \\
\text { stimulating and } \\
\text { make way to } \\
\text { utilize their } \\
\text { creativity }\end{array}$ \\
\hline $\begin{array}{c}\text { A calm and } \\
\text { pleasant } \\
\text { atmosphere at } \\
\text { work }\end{array}$ & $\begin{array}{l}\text { To foster an } \\
\text { amiable work } \\
\text { atmosphere }\end{array}$ & $\begin{array}{l}\text { Team Building } \\
\text { Focus Group } \\
\text { Discussion } \\
\text { Soft Skills Training }\end{array}$ & $\begin{array}{l}\text { July } 2021 \text { - } \\
\text { August } 2021\end{array}$ & $\begin{array}{c}\text { Management } \\
\text { Human } \\
\text { Resource } \\
\text { Immediate } \\
\text { Superior } \\
\text { Employees }\end{array}$ & HR Budget & $\begin{array}{c}90 \% \text { success for } \\
\text { work atmosphere } \\
\text { on employee } \\
\text { survey }\end{array}$ \\
\hline
\end{tabular}




\section{Conclusions}

Based on the abovementioned findings of the study, the following conclusions have been obtained:

That, Demand cause very high work stress, and Control cause high work stress among the millennial workforce in the New Normal in First Philippine Industrial Park. It was evident that working intensively and doing the same thing over and over again gives the workforce very high stress. Whereas, Support which is seldom experienced garnered low levels of work stress among the millennial workforce in the New Normal in First Philippine Industrial Park. It was evident that despite seldom having a calm and pleasant atmosphere at work, this only gives the workforce a low level of work stress.

That, Vigor and Dedication very often contribute to employee engagement among the millennial workforce in the New Normal in First Philippine Industrial Park. It was evident that persevering even when things do not go well at work makes the workforce engaged most often, and feeling proud at the work they do at work makes the workforce engaged very often. Meanwhile, Absorption often contributes to employee engagement among the millennial workforce in the New Normal in First Philippine Industrial Park. It was evident that the feeling that time flies at work makes the workforce engaged very often.

That, work-related stress specifically Demand has a significant relationship with employee engagement specifically Vigor and Dedication while Demand has no significant relationship with Absorption. Likewise, work-related stress specifically Control has a significant relationship with employee engagement specifically Dedication and Absorption while Control has no significant relationship with Vigor. Similarly, work-related stress specifically Support has a significant relationship with employee engagement specifically Vigor and Absorption while Support has no significant relationship with Dedication.

That, Work-Related Stress particularly Control significantly impacts the Employee Engagement in terms of Vigor and Dedication, while, Work-Related Stress particularly Demand and Support significantly impacts the Employee Engagement in terms of Absorption among the Millennial Workforce in the New Normal in First Philippine Industrial Park.

That the Proposed Action Plan is a helpful resource for effective strategies that companies can implement for employees to manage work-related stress and improve employee engagement in the New Normal.

\subsection{Recommendations}

Based on the outlined findings and finalized conclusions, the following recommendations are highly encouraged:

> The human resource, in cooperation with the department managers and support of the management, must give attention to the organization's measure of job demand, control, and support since these little components when combined together determines the level of the millennial workforce's work-related stress.

$>$ The human resource may consider incorporating the elements of Vigor, Absorption, and Dedication in their employee satisfaction surveys since it was proven to be effective in determining the level of employee engagement.

D The relationship between work-related stress and employee engagement may serve as a basis in formulating human resource strategies to manage stress in the workplace.

$>$ Since it was proven that work-related stress significantly impacts employee engagement, this variable can be one of the factors to focus on for companies aiming to improve employee engagement especially during this time of new normal. 
Work-related stress and employee engagement among millennial workforce in the new normal

$>$ Companies must be open to new strategies or courses of action to address their workforce's work-related stress to improve employee engagement in the new normal.

$>$ Future researchers may consider pursuing this study by involving the next generational cohort, Generation Z, given that they will be the next majority to occupy the labor force to further assess any change in factors affecting work-related stress and employee engagement.

\section{References}

Anicich, E. M., Foulk, T. A., Osborne, M. R., Gale, J., \& Schaerer, M. (2020). Getting back to the "new normal": Autonomy restoration during a global pandemic. Journal of Applied Psychology, 105(9), 931-943. https://doi.org/10.1037/ap10000655

Baran, M., \& Sypniewska, B. (2020). The impact of management methods on employee engagement. Sustainability, 12(1), 426. https://doi.org/10.3390/su12010426

Basu, S., Qayyum, H., \& Mason, S. (2016). Occupational stress in the ED: A systematic literature review. BMJ Journals, Emergency Medicine Journal, 34(7). https://doi.org/10.1136/emermed-2016-205827

Chillakuri, B., \&Mogili, R. (2018). Managing millennials in the digital era: Building a sustainable culture. Human Resource Management International Digest, 26(3), 7-10. https://doi.org/10.1108/HRMID-11-2017-0168

Chopra A., \& Bhilare P. (2020). Future of work: An empirical study to understand expectations of the millennials from organizations. Sage Journals, 8(2), 272-288. https://doi.org/10.1177/2278533719887457

Clack, L. (2020). Employee engagement: Keys to organizational success. The Palgrave Handbook of Workplace Well-Being, pp. 1-28. https://doi.org/10.1007/978-3-030-02470-3_77-1

Codd, E. (2020). White paper on millennials, gen $\mathrm{z}$ and mental health: Managing mental health in the workplace. Deloitte Article.

https://www2.deloitte.com/global/en/pages/about-deloitte/articles/millennials-gen-z-and-mental-health. $\underline{\mathrm{html}}$

Coppel, C. (2017). Learning, for when the stress ball falls. TD: Talent Development, 71(9), 18.

De Sio, S., Cedrone, F., Battagliola, E., Buomprisco, G., Perri, R., \& Greco, E. (2018). The perception of psychosocial risks and work-related stress in relation to job insecurity and gender differences: A cross-sectional study. BioMed Research International. https://doi.org/10.1155/2018/7649085

Deloitte. (2020). The Deloitte Global Millennial Survey 2020. https://www2.deloitte.com/global/en/pages/about-deloitte/articles/millennialsurvey.html

Frey, B. (2018). Cluster sampling. The SAGE encyclopedia of educational research, measurement, and evaluation. https://doi.org/10.4135/9781506326139.n117

Glazer, S., \& Liu, C. (2017). Work, stress, coping, and stress management. Oxford Research Encyclopedias, Psychology. https://doi.org/10.1093/acrefore/9780190236557.013.30

Hessels, J., Rietveld, C., \& van der Zwan, P. (2017). Self-employment and work-related stress: The mediating role of job control and job demand. Journal of Business Venturing, 32(2), 178-196.

https://doi.org/10.1016/j.jbusvent.2016.10.007

Hoppe, A., Toker, S., Schachler, V., \& Ziegler, M. (2016). The effect of change in supervisor support and job control on change in vigor: Differential relationships for immigrant and native employees in Israel. Journal of Organizational Behavior, 38(3), 391-414. https://doi.org/10.1002/job.2151

Ippoliti, F., Corbosiero, P., Canitano, N., Massoni, F., Ricciardi, M., Ricci, L., Archer, T., \& Ricci, S. (2017). Work-related stress, over-nutrition and cognitive disability. Clin Ter, 168(1), 42-47. https://doi.org/10.7417/CT.2017.1981

Jobstreet. (2019). It's more than the brand! what Filipino millennial/gen y talents really look for in a job. Laws of Attraction.

https://www.jobstreet.com.ph/en/cms/employer/laws-of-attraction/inspirations/its-more-than-the-brandwhat-filipino-millennialgen-y-talents-really-look-for-in-a-job/ 
Vigo, E. M. A.

Kadiresan, V., Wong, S., Arumugam, T., Rasu, F., \& Theseira, A. (2019). Employee engagement and retention in automotive industry in Malaysian context. Job stress as a moderator. International Journal of Engineering and Advanced Technology, 8(6S3), 607-617. https://doi.org/10.35940/ijeat.F1108.0986S319

Kerdpitak, C., \& Jermsittiparsert, K. (2020). The impact of human resource management practices on competitive advantage: Mediating role of employee engagement in Thailand. Sys Rev Pharm; 11(1), 443-452.

Khan, F., Zahra, T., Bilal, H., Sufyan, M., \& Naz, A. (2021). Does job engagement mediate the relationship between job demands and organizational commitment of academicians at institutions of higher education commission in Pakistan? Elementary Education Online, 20(5), 3533-3541. https://doi.org/10.17051/ilkonline.2021.05.388

Lajoie, A., O'Neill, N., West, T., \& Volpe, D. (2020). Stories of the pandemic: The experiences of millennial and generation y workers in Ireland. Think-Tank for Action on Social Change. https://www.tasc.ie/assets/files/pdf/

Larasati, D., Hasanati N., \& Istiqomah. (2019). The effects of work-life balance towards employee engagement in millennial generation. Advances in Social Science, Education and Humanities Research, 4th ASEAN Conference on Psychology, Counselling, and Humanities (ACPCH 2018). https://doi.org/10.2991/acpch-18.2019.93

LeBlanc, N., \& Marques, L. (2019). How to handle stress at work. Harvard Health Publishing, Harvard Medical School.

Malhotra, R. (2019). Work life balance and millennials. OJAS Expanding Knowledge Horizon, 43-44. https://jaipuria.edu.in/pgdm/wp-content/uploads/2020/04/Ojas-December-2019.pdf\#page=47

Mazzei, A. (2018). Employee engagement. Wiley Online Library. https://doi.org/10.1002/9781119010722.iesc0068

Meintjes, A., \& Hofmeyr, K. (2018). The impact of resilience and perceived organisational support on employee engagement in a competitive sales environment. SA Journal of Human Resource Management, 16(1), 1-11. https://doi.org/10.4102/sajhrm.v16i0.953

Nickolas, S. (2020). How stratified random sampling works. Investopedia.com, Corporate Finance \& Accounting, Financial Analysis. https://www.investopedia.com/ask/answers/032615/what-are-some-examples-stratified-random-samplin g.asp

Parmelee, M. (2020). The Deloitte Global Millennial Survey 2020: Highlights. Deloitte Insights. https://www2.deloitte.com/global/en/insights/topics/talent/deloitte-millennial-survey.html

Plamann, M. (2019). The impact of workplace burnout on millennial turnover. The College of St. Scholastica, ProQuest Dissertations Publishing, 2019, 8. https://search.proquest.com/openview/53d25eb67f5b44e43bdbfbb5bd0de797/1?pq-origsite=gscholar\&c bl $=18750 \&$ diss $=\mathrm{y}$

Rivers, D. (2018). A grounded theory of millennials job-hopping. Walden Dissertations and Doctoral Studies, 5936. https://scholarworks.waldenu.edu/dissertations/5936

Rutten, F. T., \& Becker, J. (2020). Comprehending millennial motivation during a crisis - The perceived influence of the employee-leader relationship. Malmö University Electronic Publishing, 56. http://hdl.handle.net/2043/32282

Saks, A. (2019). Antecedents and consequences of employee engagement revisited. Journal of Organizational Effectiveness: People and Performance, 6(1), 19-38. https://doi.org/10.1108/JOEPP-06-2018-0034

Schaufeli, W., \& Bakker, A. (2004). Utrecht work engagement scale, preliminary manual. Occupational Health Psychology Unit Utrecht University, 1(1), 25-26.

Sedat Kula. (2017). Occupational stress, supervisor support, job satisfaction, and work-related burnout: Perceptions of Turkish National Police (TNP) Members. Police Practice and Research, 18(2), 146-159. https://doi.org/10.1080/15614263.2016.1250630

Separa, L. C., Mabuting, J. A., Tolentino, S. G., Alvarez, J. E., Magbago, I. C., Alonso, J. R., \& Sargento, J. P.

72 Consortia Academia Publishing (A partner of Network of Professional Researchers and Educators) 
Work-related stress and employee engagement among millennial workforce in the new normal

(2020). Millennial mindset of employees in the authority of the freeport area of Bataan. Asia Pacific Journal of Multidisciplinary Research, 8(1), 9-15.

Sivapragasam, P., \& Raya, R. (2017). HRM and employee engagement link: Mediating role of employee well-being. Sage Journals, 19(1), 147-161.

Stankevičiūtè, Z., \& Savanevičienè, A. (2019). Can sustainable HRM reduce work-related stress, work-family conflict, and burnout? International Studies of Management \& Organization, 49(1), 79-98. https://doi.org/10.1080/00208825.2019.1565095

Van Mol, M., Nijkamp, M., Bakker, J., Schaufeli, W., \& Kompanje, E. (2018). Counterbalancing work-related stress? Work engagement among intensive care professionals. Australian Critical Care, 31(4), 234-241. https://doi.org/10.1016/j.aucc.2017.05.001

World Health Organization. (2019). Occupational health: Stress at the workplace. News Room, Q\&A Detail. https://www.who.int/news-room/q-a-detail/ccupational-health-stress-at-the-workplace

Xu, J., Liu, Y., \& Chung, B. (2017). Leader psychological capital and employee work engagement: The roles of employee psychological capital and team collectivism. Leadership \& Organization Development Journal, 38(7), 969-985. https://doi.org/10.1108/LODJ-05-2016-0126

Yunita, P., \& Saputra, I. (2019). Millennial generation in accepting mutations: Impact on work stress and employee performance. International Journal of Social Sciences and Humanities, 3(1). https://doi.org/10.29332/ijssh.v3n1.268 
Vigo, E. M. A.

74 Consortia Academia Publishing (A partner of Network of Professional Researchers and Educators) 